\title{
The School Class as an Interaction Order
}

\author{
RAF VANDERSTRAETEN, Utrecht University, The Netherlands
}

\begin{abstract}
Drawing on the works of Erving Goffman and Niklas Luhmann, it is argued that face-to-face interactions establish realities sui generis. They have a life on their own, and make demands on their own behalf. They are able to constitute their own boundaries by means of an intricate interplay of processes of reflective perception and communication. Even an organizational setting cannot determine this interaction order; it can only change the conditions within which interaction takes place. Against this theoretical background, this article analyzes the basic characteristics of the organizationally framed interaction order of classroom education. It also sketches perspectives for empirical and historical research on educational interaction in the school class. It is argued that this theoretical perspective produces a sensitive awareness of the (changing) nature of classroom interaction.
\end{abstract}

\section{Introduction}

In an excursus on 'the sociology of the senses', which is part of his monograph on sociology, Georg Simmel discusses how the perception of other people affects the perceiver, and how the five sense organs fulfil different functions in this regard. In modern times, Simmel argues, the eyes have gained a dominant position in controlling social interaction. Nineteenth-century public transportation, for example, enabled people to look at each other during extended periods of time without having to engage in a conversation with one another. In this context, Simmel draws attention to the fact that the eye can see another eye, and see that its own seeing has been seen, while an ear cannot be heard and a nose cannot be smelled. The particularities of this reflective eye contact have no exact counterpart in the domain of the other senses. According to Simmel (1992, pp. 722-742), social interaction in the modern world is largely shaped by reflective eye contact. Perception in general, then, gets organized on a new level as a consequence of social reflectivity.

In this article, Simmel's observations are used as a starting point for a discussion of social interaction with educational purposes. Education depends upon social interaction. Education typically takes place in small social units, namely, through face-to-face interactions in which the participants mutually perceive each other. These conditions determine how education is possible. They determine the consequences that ensue from 
educational interventions. In order to contribute to the development of a theory of educational interaction in the classroom, the following analysis will mainly draw on the works of Erving Goffman, Niklas Luhmann and George H. Mead. In the next section, it is argued that interactions are emergent realities that define their own boundaries. Reflective perception enables the emergence of sociality in interaction. Afterwards, some of the restraints and possibilities of organizationally framed interaction in general and of classroom interaction in particular are discussed. I conclude with a brief presentation of three educational research perspectives that incorporate the theoretical arguments of this article.

\section{The Interaction Order}

At present, the significance of Erving Goffman's contribution to the study of social interaction is widely recognized. Goffman focused foremost on the detailed description of patterns of individual and social behaviour in the most diverse settings. But he also tried to provide a theoretical and analytical rationale for the separate treatment of social interaction - most notably in 'The Interaction Order', his presidential address to the 1982 Annual Convention of the American Sociological Association, which was in fact never delivered and published posthumously (Goffman, 1983). In retrospect, Goffman's contribution to 'social theory' can be seen to consist in the elaboration of this idea of an interaction order sui generis (Rawls, 1987). Throughout his scholarly work, he attempted to indicate that participation in interaction creates a meaning that cannot be attributed to the subject or to the object of perception, and that neither ensues from both the subject and the object together. Interaction creates a new level on which reality is structured. It 'has a life on its own and makes demands on its own behalf. It is a little social system with its own boundary-maintaining tendencies' (Goffman, 1966, p. 113). This interaction order is, according to Goffman, constituted by an intricate interplay of perceptual processes and communication among persons who are together. Its situational closure is established within the interaction itself.

Niklas Luhmann's argument goes in the same direction. Interaction systems 'conceive of themselves as face-to-face interactions and use the presence of persons as a boundarydefining device. If new persons arrive, their communications have to be included into the system by some ceremonial recognition and introduction' (Luhmann, 1987, p. 114; cf. Luhmann, 1995, pp. 412-416). What is socially relevant is determined among those present. This means that interaction orders reserve for themselves the ability to decide who and what will count as being present. Interaction does not simply include everyone who is present and perceivable, and only these. Servants for example, could be treated as absent, even when they were present in the same room. The waiter in a restaurant is sometimes present, and sometimes absent - depending on whether he/she does or does not get included in the conversation among the dinner guests. The situation is similar for the individual who is momentarily left to his/her own resources, while a person to whom he/she has been talking answers a telephone call. Participation or inclusion in interaction does, in other words, not result from the mere presence of human bodies in a room. It is regulated by means of communication, and mostly by means of communication among those who are present. The interaction order is an emergent reality that creates in this regard its own boundaries.

Through perception, interaction achieves the capacity for complementing explicit communication by (intended or unintended) indirect communication, where the risks of explicit action can be avoided. Indirect communication is, for example, important as a 
level for making sexual advances, but also for working out changes in theme, making an end to a contact, etc. Equally important, reflective perceiving forces communication to go on. If you perceive that you are perceived and that this perception of being perceived is perceived, you have to assume that your behaviour gains social relevance (whether this suits you or not). Reflective perception will force you to control your behaviour as social behaviour, i.e. as communication. Even the communication of not wanting to communicate (e.g. looking out the window, hiding behind a newspaper) is communication. One cannot not communicate in an interaction situation. One must withdraw from the interaction if one wants to avoid communication.

The importance of perception gives the bodies of the participants a strategic significance in communication. Processes of 'modernization' or 'civilization' are characterized by increased bodily discipline, as the famous analyses of Norbert Elias (1978) have made clear. In my view, George H. Mead's analyses of 'gestures' can also be read in this regard, i.e. as an indication of the social uses of the body (see, for example, Mead, 1934, pp. 13-18). The sociality of a gesture ensues from the generalization of meaning. The gesture has social relevance if it 'is addressed to the self when it is addressed to another individual, and is addressed to another, in form to all other individuals, when it is addressed to the self (Mead, 1964, p. 246). Mead does not explain how a bodily movement can be specified so that it can serve as an adequately specific trigger of another's behaviour. He does not explain how two bodies attain an adequately specified interplay. However, Mead clearly indicates that the generalization of meaning attained within social interaction provides for additional degrees of freedom (see Biesta, 1998). Meaning-constituted boundaries are more capable of abstraction than any other kind of system boundaries; more than any other kind (e.g. spatial boundaries such as walls), they are self-generated boundaries.

An important source, which clearly displays the interplay of perception and communication, to which Goffman and Luhmann refer, is the literature on 'the art of conversation' and sociable interaction, which started to appear from the sixteenth century onwards (see, for example, Burke, 1993). Some brief examples from different European contexts may illustrate my point. In Claude Buffier's Traité de la Société Civile, it is argued that it would be very impolite to say that one is bored with another's company and, therefore, it becomes part of politeness to keep an eye out to see whether the other is getting bored. In other words, politeness is reflective in that it avoids exploiting another person's politeness, and this requires bringing in the level of perception (Buffier, 1726, pp. 123-125). Also, it is argued that one has to avoid sharp contradictions and the expression of opinions that may hurt others who are present. Even praise must be handled carefully, lest it be taken for flattery by the addressee or by an observer (cf. Bessel, 1763, pp. 55-62). Furthermore, interruptions of speakers are considered to be crude, while periods of silence are thought of as painful. One finds, in John Locke's Some Thoughts Concerning Education, the following advice: 'Young Men should be taught not to be forward to interpose their Opinions, unless asked, or when others have done, and are silent; ... when a general Pause of the whole Company affords an Opportunity, they may modestly put in their Question as Learners' ([1693] 1902, pp. 126-127). In the course of the societal evolution, increasing demands are made on socially reflective sensitivity in interaction situations. One must carefully observe the other and calculate one's own behaviour from the other's point of view. Current patterns of social interaction are at the same time the outcome of contingent historical developments.

Society has developed numerous patterns and social conventions that give form to interactions. This historical evolution seems to underpin the idea that interactions only 
specify societal norms and value orientations that provide for a normative consensus (Misztal, 1996; see also Parsons, 1968). Societal conventions do indeed often suffice to indicate and structure interaction orders. However, one can deviate from these conventions; rules can be broken, or the opportunities they create can be used selectively. For example, you meet some people you know and greet them - in order to get by them. Or, you greet someone you know legitimately, and are thus entitled to a greeting in return. But the greeting can be returned so as to display an unwillingness to engage in interaction (see Goffman, 1983). Some forms of interaction suggested by social conventions can be used to avoid interactions. The interaction order is autonomous with regard to the regulation of communication. There is, as Goffman and Luhmann have indicated, a theoretical rationale for the separate treatment of interaction, for its treatment as a boundary-maintaining social system in modern times.

\section{Organizationally Framed Interaction}

One of the most dominant characteristics of modern society is the widespread proliferation of organizations. This historical development-often discussed in terms of rationalization and bureaucratization (see Weber, 1978)-also touched upon interaction. Interaction now predominantly takes place in organizational settings. Governors, for example, have been replaced by schoolteachers who work within an organizational setting. But notwithstanding this organizational 'framing' (Goffman, 1975), interaction cannot simply be 'instrumentalized' for organizational purposes. It cannot simply be turned into a means that realizes particular organizational ends (as teachers know). On the other hand, organizations create a structure for the interaction, at the least because interaction now takes place between the members of an organization. To exemplify the impact of the organizational setting on interaction situations, and vice versa, some particular characteristics of organized interaction can be indicated (see Kieserling, 1999, pp. 335-387).

(a) Interaction in organizations is often defined in terms of 'work'. One's presence at work is motivated by the benefits of organizational membership, not by the delights of the social interaction (for example, Habermas, 1976). The possibility of social interaction depends in this account on the organization; interaction is regulated by the organization. However, organizational possibilities also depend on informal or deregulated interaction. The attitude towards tolerating professional mistakes, which Goffman (1961) observed among many surgeons for example, is from the perspective of the organization of the hospital itself a mistake. In the interaction system of a surgical operation, however, this attitude fulfils important functions. Explicitly pointing to the mistake made by one of the surgeons would divert the attention of the participants. Moreover, it would impinge upon the presentation of self of the addressee, and his/her reaction might really endanger the interaction. In particular cases, deregulated interactions can prove to be functional for the organization. More generally, it can be stated that the autonomy of the interaction order hinders its straightforward utilization in organizations. The organizational framing makes it possible to regulate interaction in terms of special conditions and special functions, but also allows for deregulated interaction. Regulation and informality come from the same root.

(b) Within an organization, recurrent contacts between the members of the organization are evident. Joint membership guarantees the continuation of the interaction. It does 
not depend on the outcome of preceding interactions, or on individual willingness to participate. The relationship between the participants can be, and can remain, relatively neutral. Motives for being present exist independent of the interaction situation. A teacher does not return to a class because she likes to work with the class, but because the school organization makes arrangements for recurrent meetings. Presentations of self that nevertheless focus on previous interaction experiences almost inevitably ask for 'critical' questions, e.g. regarding someone's 'real' motives (Why does he/she praise us? What is he/she up to? What does he/she want of us?). Suspicion as to 'real' motives develops almost automatically in these settings. The organization establishes premises that cannot-or can only through paradoxical communication - be challenged in the interaction (see Weick, 1995). The improbability that a group of people (each of whom also fulfils other roles) recurrently meets seems to get normalized by organization, but in such a way that an explication in terms of 'mutual sympathy' is excluded. In this sense, organization disrupts the connection between intensified social contacts and solidarity, which Emile Durkheim (1972) and many social scientists after him presupposed.

(c) If one's presence in the interaction is guaranteed by the organization, a kind of motivational indifference becomes normal. Particular commitment to organizational goals is not excluded, but it will become very visible. If mere presence is sufficient, the contrast of high commitment attracts all the more attention. In our post-modern society, this kind of situation is mostly observed by means of a scheme that distinguishes goals and motives. In organizations, there are the goals for which one gives one's very best, and there are the motives behind one's behaviour (e.g. careerist motives). Interestingly, the actor and the observer attribute the causes of behaviour in different ways (Jones \& Nisbet, 1972). Actors typically indicate that they are interested in the work in itself. The organization normally also articulates targets whose realization is explicitly valued. But this does not preclude that observers discuss the actor's motives, and that eventually plans are made to thwart these presumed motives. Too diligent pupils often fall victim to the counterstrategies of their classmates. Apart from the problem of harassment, still very little is known today of the psychological impact of organizationally framed interaction (see also Vanderstraeten, 2000). It would, in my view, be worthwhile to study the impact of this goal/motive observational scheme on the way one indulges in one's work.

It would be wrong to infer from this brief characterization of organized interaction that 'organization' has only led to the emergence of patterns of amoral behaviour. It would also be wrong to infer that organizational structures only curtail interaction freedom. The relation between imposing restrictions on, and allowing the extension of, interaction freedom is more complicated. Organizational framing introduces restrictions that are able to provide for greater complexity. What is possible in normal societal interaction is not always possible in an organized setting. But particular organizational limitations sometimes enable to realize a considerable surplus value in the interaction. The complexities of classroom education are a good example of this intricate interplay of interaction and organization systems.

\section{Glassroom Interaction}

The 'groundwork' for classroom interaction is laid outside the classroom, and outside the school. A large number of structural arrangements are beyond its control, such as the 
asymmetrical structure of the classroom (one teacher, a number of students of about the same age), the hierarchical relationship between teacher and pupils, the timetable, the subject matter that should be taught c.q. learned. The customary spatial and architectural arrangements - rectangular rooms, aligned benches, pupils who face the teacher but not one another, etc.-complement this structural groundwork (see, for example, Reid, 1986, pp. 58-93; Hargreaves, 1994, pp. 95-116; Markus, 1996). Moreover, the value of schooling is widely promulgated and widely accepted as obvious in our Western society, although different groups may see its value differently. Because siblings and parents of children now at school have normally themselves attended schools, schooling appears as a 'natural' stage in growing up (see Vanderstraeten, 1999, 2000b). The activities of the other teachers and the head in the classrooms, corridors and hall of course also provide the foundation upon which a teacher and their pupils build in the classroom.

However, this groundwork does not remove the necessity for the teacher to establish and defend their authority, and to create an environment that elicits learning experiences. In an older, but still noteworthy, article that focuses on strategies teachers adopt to establish their authority in the classroom, Martyn Hammersley wrote: 'To the extent that the teacher successfully imposes an asymmetrical "order" on classroom interaction, he turns his claimed authority into a fact to be reckoned with. By successfully demanding attention and disciplined participation, the teachers actually "demonstrate" their competence as teachers, that they are teachers, and therefore their "superiority" to pupils" (1976, p. 111). Most pupils know the 'official' criteria, and can judge the teachers' behaviour accordingly. They are able to distinguish between good and bad, strong and weak, soft and strict teachers. "Any "failure" to maintain "discipline", whatever the motive, is in danger of being seen as weakness, and thus lack of "authority" and of being exploited by pupils' (p. 112). These observations indicate that the interaction order of the classroom is constructed within the interaction itself (see also Pollard, 1985, pp. 154-171; Hammersley, 1990, pp. 101-113, 1994, pp. 153-160). It cannot be programmed, despite the structural and cultural 'groundwork'. However, the interaction reflects these external conditions in itself.

In comparison with other domains of social life, the educational system has in fact hardly been able to establish and impose reliable forms of organizational control. Education is therefore very 'vulnerable' (Welker, 1992). In classroom education, goals cannot be attained without the commitment of the pupils, while on the other hand this commitment cannot be organizationally enforced. The teacher is, as Dan Lortie noted, 'expected to elicit work from students. Students in all subjects and activities must engage in directed activities which are believed to produce "learning" ... The teacher therefore must "motivate" students, within the constraints described, to work hard and, if possible, to enjoy their efforts. He cannot count on voluntary enthusiasm: the teacher must generate much of the positive feeling that animates purposeful effort. All this, moreover, must be accomplished within a group setting' (1975, pp. 151-152). Educational organizations lack, as Lortie argued (see also Luhmann \& Schorr, 2000), an adequate and reliable technology. The results of particular interventions cannot be foreseen or planned in organizational headquarters. The sources of success or failure cannot be exactly identified. Education is highly dependent on the dynamics of the interaction order.

It is a general characteristic of the so-called 'people processing' organizations (e.g. spiritual, medical, legal, or therapeutic systems of help) that organizational goals are difficult to achieve without the commitment of their clients. This characteristic might explain the high degree of professional autonomy and the importance of face-to-face 
interactions in the course of the 'treatment' (Abbott, 1988). There is, however, great variation within the professional organizations in this regard. Clients often enrol in 'people processing' organizations because of biographical crises, and thus do not need to be urged on to collaborate. They long for this help, and are willing to pay for it. Here, education finds itself in an exceptional position. Because children have to go to school (at least at the primary and secondary level), this source of voluntary enthusiasm or commitment mostly fails. Schools have to deal with a particularly critical audience. Accordingly, one finds numerous and often very inventive 'opting-out' strategies in educational interactions - that all make use of perception, and of the perception of perception. Pupils are continually engaged in reading the behaviour of their teacher. Observing whether one is being observed or is temporary out of the teacher's sight, hiding behind another one's back, pretending that one listens attentively, looking as if everything what is said is understood, etc.

It is, in this context, interesting to point to some historical developments that have accompanied the generalization of classroom education. In the educational literature that appeared at the end of the eighteenth century, the very possibility of education in the classroom became an important topic. One doubted, for example, whether a teacher could exercise educational authority, because there were no blood-ties between the teacher and her pupils (for example, Niemeyer, [1796] 1970). Elsewhere, it has been argued that the generalization of classroom education depended upon an organizational 'deactivation' of the instability of educational relationships (see Vanderstraeten \& Biesta, 2001). In this process of 'restabilization', the curriculum fulfilled (and furthermore fulfils) an important role. The morphogenesis of the modern educational system encompassed a number of interrelated changes: the so-called discovery of the child, the professionalization of teaching, and the development of new curricular principles (Allgemeinbildung). It is no coincidence that these developments occurred in the same period, and mutually reinforced each other. The triadic structure was indispensable for the morphogenesis of the modern system of education. Until today, the curriculum specifies what needs to be learned at school. This way, it unburdens the teacher; it reduces the tensions between teachers and pupils. In schools, one focuses on what needs to be learned. This organizational condition partly normalizes the improbability of educational interaction in the classroom.

In the modern school class, there develops an interaction order among those present. Organizational arrangements have, as we discussed, a bearing on this interaction. But they do not simply restrict degrees of freedom of the interaction. They create opportunities that would not be available without the school organization. Restrictions on and extensions of these degrees of freedom go together and depend on each other. To conclude this paper, I will briefly discuss three research perspectives that might highlight particular characteristics of the educational interaction in the classroom.

(a) The asymmetrical structure of the interaction order of the school class puts a burden on the teacher. As the 'authority', he/she has to control the interaction. But this is not a linear process. It involves taking into account what pupils might do, how they are likely to respond to various different possible measures, what the chances are of each of these measures succeeding, at what cost in time, effort and face, etc. One might conclude that it is the controller who is being controlled (cf. Hargreaves, 1978, pp. 73-100; Vanderstraeten, 1997). The interaction imposes its own order; it has a life on its own and makes demands on its own behalf. An interesting question is whether, and how, the characteristics of this interaction order have changed in the 
course of the nineteenth and twentieth centuries. For example, it seems likely that the complexities of classroom interaction have varied. In a traditional regime, in which pupils have to sit still, fold their arms, look straight ahead, beg permission to speak, etc., the range of alternatives the teacher has to consider is clearly restricted. The habits and routine behaviours of teachers, which enable them to (re)act on the spur of the moment, will accordingly have been relatively straightforward. From the perspective of a theory of classroom history, the problem is to find ways to come to grips with this fleeting reality in an (almost) invariant organizational setting. Recent micro-historical research has focused attention on the remarkable persistence of the so-called 'grammar of schooling', and has attributed it to the dominance of (stereo)typical organizational structures (for example, Tyack \& Cuban, 1995; Rousmaniere, 1997; Grosvenor et al., 1999; Depaepe, 2000). My suggestion is that the concept of 'interaction order' can provide classroom history with a powerful theoretical tool for interpreting both patterns of continuity and of discontinuity in classroom interaction. The boundaries of the interaction order cannot be defined by the organizational setting, but are created in the interaction itself.

(b) The organizational 'normalization' or 'restabilization' of educational interaction has a price. The organizational setting of the school class unavoidably imposes particular distinctions, such as good/wrong, praise/reprimand, succeed/fail (more generally, positive/negative). Concretizations of pedagogical behaviour are laden with difference; they indicate lines of success and thereby establish the possibility of failure. Despite good intentions, pedagogical means transform equality into inequality. They motivate and discourage. They link experiences of success to experiences of success, and experiences of failure to experiences of failure (Luhmann, 1995, p. 207; Chervel, 1998). One of the questions that should be raised in this regard is how children react when they are constantly confronted with this option and when they are constantly pressed to conform to their parents' and teachers' expectations. In our postmodern, individualistic society, it makes sense - and more than ever before - to assume that they will look for some kind of 'opting-out' strategy. Deviating from normal expectations offers the best opportunities to display one's individuality. For example, pupils may react with unexpectedly good performance, with nonchalance vis-à-vis evaluation criteria, with cynicism and sarcasm, with the cultivation of a deviant school or youth subculture, with the invention of slang language, with alternative assessments of qualities and personal merits, etc. Classroom education enforces, in other words, a choice between adaptation and deviance. Pupils cannot be obliged to internalize the culture of the older generations. The theoretical articulation of the autonomy of the interaction order underpins the critique of the fairly deterministic assumptions of traditional research on socialization. It allows paying attention to both the positive and the negative effects that ensue from organizationally framed educational interaction.

(c) If an elaborate apparatus of goals, tests, interventions, etc. is put to use to attain a certain output, the aforementioned unintended and mostly unforeseen effects will be multiplied and will bring about particular ramifications. One can describe these effects as secondary socialization - 'secondary' not understood as what follows upon primary socialization in the family, but understood as the consequence of the particular organizational settings within which education occurs. Some of these effects are currently pretty well known. As the so-called hidden curriculum, they have been (and continue to be) the objects of extensive research (see Wexler, 1987; Maxwell \& Maxwell, 1995; Englund, 1997). This research perspective, however, 
mainly focuses on the structural determination of classroom education. It hardly pays attention to the typicalities, peculiarities and consequences of the unstructured or deregulated interactions in organizational setting. But, as we have seen, this deregulated interaction may produce its own effects. Participation in deregulated interaction may deeply influence the habitus or self-concept that each student develops (for example, unexpected events, surprising reactions, occasional deviant or conformist behaviour). The interaction order of the school class is susceptible to both structural and operational forms of determination (see Kupferberg, 1996; Vanderstraeten, 2000). Research on secondary socialization should, therefore, focus on the wide range of consequences of organized interaction.

During the previous decade, the demise of sociology of education has been frequently recorded (for example, Ball, 1995; Hammersley, 1996). After the debates related to the 'new sociology of education' of the 1970s and 1980s, the field has been unable to develop convincing theoretical and empirical research programs. The prevailing opinion among researchers nowadays is that the requirements of theory and concrete facts will never meet. As I have tried to argue in this article, however, it is a lack of good theory, not something intrinsic about sociology, that has prevented convincing sociological research on the nature of educational interaction. Contemporary sociological theories are not sufficiently abstract to allow the kind of complex research design that educational research demands. These theories are unable to come to terms with empirical research findings that highlight the many complexities of classroom interaction.

Abstract theories in the field of sociology of education have hitherto been strongly inspired by macro-analyses. The micro-macro link has shaped the discussions since Talcott Parsons's influential 'The School Class as a Social System' (Parsons, 1959; cf. Hammersley, 1994, pp. 153-160). Based on the theoretical work of Erving Goffman and Niklas Luhmann, I have argued that the school class needs to be understood as an interaction order. It has a life on its own and makes demands on its own behalf. This perspective provides us with a more powerful conceptualization. When it is applied, the much-discussed gap between theoretical and empirical research programs loses a lot of its importance. This perspective is able to produce a sensitive awareness of the (changing) nature of classroom interaction. Insight into the diversity and complexity of the attitudes and activities of teachers and pupils does not simply ensue from empirical or micro-historical research. One needs a (complex) theory to be able to observe the characteristics of educational interaction in the school class.

\section{Acknowledgements}

The original draft of this paper was presented at a symposium organized in Utrecht in honour of Gert Biesta, on the occasion of his move from Utrecht University to the University of Exeter near the end of 1999. Thanks are due to the participants at this symposium, and to the anonymous reviewers of the British Fournal of Sociology of Education. 


\section{REFERENGES}

Аввотт, A. (1988) The System of Professions. An essay on the division of expert labor (Chicago, IL, University of Chicago Press).

BaLL, S.J. (1995) Intellectuals or technicians? The urgent role of theory in educational studies, British Fournal of Educational Studies, 43, pp. 255-271.

Bessel, C.G. (1763) Schmiede deß Politischen Glüks darinnen viele nützliche Lehren enthalten (Franckfurt, Naumann).

Biesta, G.J.J. (1998) Mead, intersubjectivity, and education: the early writings, Studies in Philosophy and Education, 17, pp. 73-99.

Buffier, C. (1726) Traité de la Société Civile, et du Moyen de se Rendre Heureux, en Contribuant au Bonheur des Personnes avec Qui l'on Vit (Paris, Giffart).

Burke, P. (1993) The Art of Conversation (New York, Cornell University Press).

Chervel, A. (1998) La Culture Scolaire: une approache historique (Paris, Belin).

Depaepe, M. (2000) Order in Progress: everyday educational practice in primary schools, Belgium, 1880-1970 (Leuven, Leuven University Press).

Durkheim, E. (1972) The Division of Labor in Society (New York, Free Press).

Elias, N. (1978) The Civilizing Process: the history of manners (New York, Urizen Books).

ENGLund, T. (1997) Towards a dynamic analysis of the content of schooling: narrow and broad didactics in Sweden, Joumal of Curriculum Studies, 29, pp. 267-287.

Goffman, E. (1961) Encounters: two studies in the sociology of interaction (Harmondsworth, Penguin University Books).

Goffman, E. (1966) Interaction Ritual (New York, Doubleday Anchor).

Goffman, E. (1975) Frame Analysis, An Essay on the Organization of Experience (Cambridge, MA, Harvard University Press).

Goffman, E. (1983) The interaction order, American Sociological Review, 48, pp. 1-17.

Grosvenor, I., Lawn, M. \& Rousmaniere, K. (1999) Silences and Images (Frankfurt am Main, Peter Lang). Habermas, J. (1976) Arbeit und Interaktion, in: Technik und Wissenschaft als 'Ideologie' (Frankfurt am Main, Suhrkamp).

Hammersley, M. (1976) The mobilisation of pupil attention, in: M. Hammersley \& P. Woods (Eds) The Process of Schooling. A sociological reader (London, Routledge \& Kegan Paul).

Hammersley, M. (1990) Classroom Ethnography: empirical and methodological essays (Buckingham, Open University Press).

Hammersley, M. (Ed.) (1994) Some reflections on the macro-micro problem in the sociology of education, in: Controversies in Classroom Research, 2nd edn. (Buckingham, Open University Press).

Hammersley, M. (1996) Post mortem or post modern? Some reflections on British sociology of education, British Fournal of Educational Studies, 1996, pp. 395-407.

Hargreaves, A. (1978) The significance of classroom coping strategies, in: L. Barton \& R. Meighan (Eds) Sociological Interpretations of Schooling and Classrooms: a reappraisal (Nafferton, Nafferton Books).

Hargreaves, A. (1994) Changing Teachers, Changing Times. Teachers' work and culture in the Postmodern age (London, Cassell).

Jones, E.E. \& Nisbet, R.E. (1972) The actor and the observer: divergent perceptions on the causes of behavior, in: E.E. Jones et al. (Eds) Attribution: perceiving the causes of behavior (Morristown, NJ, Central Learning Press).

Kieserling, A. (1999) Kommunikation unter Anwesenden. Studien über Interaktionssysteme (Frankfurt am Main, Suhrkamp).

Kupferberg, F. (1996) The reality of teaching: bringing disorder back into social theory and the sociology of education, British Foumal of Sociology of Education, 17, pp. 227-247.

Locke, J. (1902) in: R.H. Quick (Ed.) Some Thoughts Concerming Education, (Cambridge, Cambridge University Press).

LoRtie, D.C. (1975) Schoolteacher: a sociological study (Chicago, IL, University of Chicago Press).

Luhmann, N. (1987) The evolutionary differentiation between society and interaction, in: J.F. Alexander et al. (Eds) The Micro-Macro Link (Berkeley, CA, University of California Press).

Luhmann, N. (1995) Social Systems (Stanford, CA, Stanford University Press).

Luhmann, N. \& Schorr, K.E. (2000) Problems of Reflexivity in the System of Education (London, Bergbahn Books).

Markus, T. (1996) Early nineteenth century school space and ideology, Paedagogica Historica, 34, pp. 93-126.

Maxwell, J.D. \& Maxwell, M.P. (1995) The reproduction of class in Canada's elite independent schools, British Journal of Sociology of Education, 16, pp. 309-326.

Mead, G.H. (1934) in: C.W. Morris (Ed.) Mind, Self, E्E Society, from the Standpoint of a Social Behavionist (Chicago, IL, University of Chicago Press).

Mead, G.H. (1964) in: A.J. Reck (Ed.) Selected Writings (Chicago, IL, University of Chicago Press).

Misztal, B.A. (1996) Trust in Modern Societies (Cambridge, Polity Press). 
Niemeyer, A.H. (1970) Grundsätze der Erziehung und des Unterrichts für Eltern, Hauslehrer and Erzieher (Paderborn, Schöningh).

Parsons, T. (1959) The school class as a social system: some of its functions in American society, Harvard Educational Review, 29, pp. 297-318.

Parsons, T. (1968) Social interaction, in: D. Sills (Ed.) International Encyclopedia of the Social Sciences, vol. 12 (New York, Macmillan \& Free Press).

Pollard, A. (1985) The Social World of the Primary School (London, Holt, Rinehart \& Winston).

Rawls, A.W. (1987) The interaction order sui generis: Goffman's contribution to social theory, Sociological Theory, 5, pp. 136-149.

ReID, I. (1986) The Sociology of School and Education (London, Fontana).

Rousmaniere, K. (1997) City Teachers. Teaching and School Reform in Historical Perspective (New York, Teachers College Press).

Simmel, G. (1992) Soziologie (Frankfurt am Main, Suhrkamp).

Tyack, D. \& Cuban, L. (1995) Tinkering towards Utopia. A century of public school reform (Cambridge, MA, Harvard University Press).

VAnderstraeten, R. (1997) Circularity, complexity and educational policy planning. A systems approach to the planning of school provision, Oxford Review of Education, 23, pp. 321-332.

VANDERStRAETEN, R. (1999) Educational expansion in Belgium: a sociological analysis using systems theory, Fournal of Education Policy, 14, pp. 507-522.

Vanderstraeten, R. (2000) Autopoiesis and socialization. On Luhmann's reconceptualization of communication and socialization, British Fournal of Sociology, 51, pp. 581-598.

VAnderstraeten, R. (2000b) The sociological analysis of educational expansion, in: S.J. Ball (Ed.) The Sociology of Education: Major Themes. Volume 1: Theories and Methods (pp. 492-505) (New York, Routledge).

Vanderstraeten, R. \& Biesta, G.J.J. (2001) How is education possible? Preliminary investigations for a theory of education, Educational Philosophy and Theory, 32, pp. 7-21.

Weber, M. (1978) Economy and Society, An Outline of Interpretive Sociology (Berkeley, CA, University of California Press).

WEICK, K.E. (1995) Sensemaking in Organizations (Thousand Oaks, CA, Sage).

Welker, R. (1992) The Teacher as Expert: A theoretical and historical examination (New York, SUNY Press). Wexler, P.H. (1987) Social Analysis of Education. After the new sociology (London, Routledge \& Kegan Paul). 